\title{
Distribution and Characterization of Podosphaera macularis Virulent on Hop Cultivars Possessing R6-Based Resistance to Powdery Mildew
}

Sierra N. Wolfenbarger, Oregon State University, Department of Botany and Plant Pathology, Corvallis, OR 97331; Stephen T. Massie, United States Department of Agriculture-Agricultural Research Service (USDA-ARS), Forage Seed and Cereal Research Unit, Corvallis, OR 97331; Cynthia Ocamb and Emily B. Eck, Oregon State University, Department of Botany and Plant Pathology; Gary G. Grove, Mark E. Nelson, and Claudia Probst, Washington State University, Irrigated Agriculture Research and Extension Center, Prosser, WA 99350; Megan C. Twomey, Oregon State University, Department of Botany and Plant Pathology; and David H. Gent, Oregon State University, Department of Botany and Plant Pathology and USDA-ARS, Forage Seed and Cereal Research Unit

\begin{abstract}
Wolfenbarger, S. N., Massie, S. T., Ocamb, C., Eck, E. B., Grove, G. G., Nelson, M. E., Probst, C., Twomey, M. C., and Gent, D. H. 2016. Distribution and characterization of Podosphaera macularis virulent on hop cultivars possessing R6-based resistance to powdery mildew. Plant Dis. 100:1212-1221.

Host resistance, both quantitative and qualitative, is the preferred long-term approach for disease management in many pathosystems, including powdery mildew of hop (Podosphaera macularis). In 2012, an epidemic of powdery mildew occurred in Washington and Idaho on previously resistant cultivars whose resistance was putatively based on the gene designated $R 6$. In 2013, isolates capable of causing severe disease on cultivars with $R 6$-based resistance were confirmed in Oregon and became widespread during 2014. Surveys of commercial hop yards during 2012 to 2014 documented that powdery mildew is now widespread on cultivars possessing $R 6$ resistance in Washington and Oregon, and the incidence of disease is progressively increasing. Pathogenic fitness, race, and mating type of $R 6$-virulent isolates were compared with isolates of $P$. macularis lacking $R 6$ virulence. All isolates were positive for the mating type idiomorph MAT1-1 and were able to overcome resistance genes $R b, R 3$, and $R 5$ but not $R 1$ or $R 2$. In addition, $R 6$-virulent isolates were shown to infect differential cultivars reported to

possess the $R 6$ gene and also the $R 4$ gene, although $R 4$ has not yet been broadly deployed in the United States. $R 6$-virulent isolates were not detected from the eastern United States during 2012 to 2015. In growth chamber studies, R6-virulent isolates of $P$. macularis had a significantly longer latent period and produced fewer lesions on plants with $R 6$ as compared with plants lacking $R 6$, indicating a fitness cost to the fungus. $R 6$-virulent isolates also produced fewer conidia when compared with isolates lacking $R 6$ virulence, independent of whether the isolates were grown on a plant with or without $R 6$. Thus, it is possible that the fitness cost of $R 6$ virulence occurs regardless of host genotype. In field studies, powdery mildew was suppressed by at least $50 \%$ on plants possessing $R 6$ as compared with those without $R 6$ when coinoculated with $R 6$-virulent and avirulent isolates. $R 6$ virulence in $P$. macularis appears to be race specific and, at this time, imposes a measurable fitness penalty on the fungus. Resistance genes $R 1$ and $R 2$ appear to remain effective against $R 6$-virulent isolates of $P$. macularis in the U.S. Pacific Northwest.
\end{abstract}

Host resistance is often regarded as the ultimate disease management solution in many pathosystems because of its simplicity and efficiency (Agrios 2005; McDonald 2014; Wolfe 1984). The classic gene-for-gene concept proposed by Flor (1955) is attributable to an interaction between effectors in the pathogen and effector-specific resistance genes in the host (Ellis et al. 1999; Gabriel 1999). Major resistance $(R)$ genes are deployed in a variety of crops against many diseases. They confer resistance by the detection of an effector or monitor interference with pattern recognition receptors in the host, thus signaling upregulation of an immune response (Jones and Dangl 2006; Stotz et al. 2014). However, major $R$ genes are often overcome by virulent strains of a pathogen due to loss or mutation of an effector. Consequently, breeding for disease resistance in many agricultural crops necessitates ongoing identification and introgression of new resistant genes (Thompson and Burdon 1992).

\section{Corresponding author: D. H. Gent; E-mail: dave.gent@ars.usda.gov}

Disclaimer: The use of trade, firm, or corporation names in this publication is for the information and convenience of the reader. Such use does not constitute an official endorsement or approval by the United States Department of Agriculture or the Agricultural Research Service of any product or service to the exclusion of others that may be suitable.

*The $\boldsymbol{e}$-Xtra logo stands for "electronic extra" and indicates that one supplementary figure is published online.

Accepted for publication 1 February 2016.

http://dx.doi.org/10.1094/PDIS-12-15-1449-RE

This article is in the public domain and not copyrightable. It may be freely reprinted with customary crediting of the source. The American Phytopathological Society, 2016.
Breeding for host resistance to powdery mildew on hop, caused by Podosphaera macularis, began in the early 1900s and continues to be a primary breeding focus in many breeding programs worldwide (Neve 1991; Salmon 1917). This is especially true for the U.S. Pacific Northwest (Washington, Oregon, and Idaho), where the disease became a major constraining factor for hop production after the introduction of the pathogen to the region in 1996 (Ocamb et al. 1999). To date, seven $R$ genes have been recognized in hop (named $R B, R 1, R 2, R 3, R 4, R 5$, and $R 6$ ) that can impart immunity to select isolates of $P$. macularis (Neve 1991; Seigner et al. 2001).

Molecular mechanisms underlying the function of these $R$ genes are unknown (Seigner et al. 2001). However, Henning et al. (2011) identified a quantitative trait locus (QTL) associated with powdery mildew reaction in a mapping population derived from 'Perle' and the powdery mildew resistant male 'USDA 19058M'. USDA 19058M is the grandfather of 'Nugget', both of which express resistance attributed to R6. Henning et al. (2011) found that the absence of a particular major locus, as indicated by two flanking markers in susceptible but not resistant individuals, predicted immunity to powdery mildew in the population. This suggests that the resistance associated with $R 6$ may, in fact, be due to the lack of a susceptibility gene rather than the presence of an $R$ gene. Susceptibility genes typically function as a dominant allele at a locus and confer susceptibility to a disease because the gene product serves as a target for one or more pathogens (Schouten et al. 2014; Seifi et al. 2014). A nonfunctional, recessive mutation of this allele may confer nonhost, broad-spectrum resistance (Nürnberger and Lipka 2005; van Schie and Takken 2014). Susceptibility loci are thought to be widespread among all taxa of plants (van Schie and Takken 2014). The classical example of a susceptibility locus is the mildew resistance locus $\mathrm{O}$ (mlo) in barley, which confers stable, broad-spectrum resistance against Blumeria 
graminis, whereas the functional, dominant genotype, Mlo, is fully susceptible (Jørgensen 1992).

Recently, isolates of P. macularis were discovered in the Pacific Northwest that are capable of overcoming R6-based resistance, and outbreaks of powdery mildew have occurred on previously resistant cultivars (Wolfenbarger et al. 2014b). Cultivars that putatively possessed $R 6$ were deployed on approximately $25 \%$ of the hop acreage in the region in 2012 and, given this selective pressure, it is perhaps unsurprising that virulent strains of the fungus emerged. Because hop plants are long-lived perennials, there is an urgent need to understand the distribution of $R 6$-virulent isolates of $P$. macularis in the region, and the susceptibility of formerly resistant cultivars, so that management actions can be appropriately scaled to cultivar susceptibility.

In the longer term, efficient breeding for resistance to powdery mildew would be facilitated by an enhanced understanding of the virulence structure of the pathogen population and the continued breeding value of $R 6$, if any, in disease resistance. Overcoming an $R$ gene may impose a fitness penalty on a pathogen, potentially rendering even a defeated $R$ gene beneficial to host resistance (Leach et al. 2001) and effectively converting an $R$ gene into a QTL. Measuring pathogenic fitness often is inferred from measurements of fecundity or disease severity, calculation of demographic parameters, or directly through competition studies (Leach et al. 2001; Nelson 2012). Fitness penalties associated with enhanced virulence may be relatively small or nonexistent in some instances due to the specific function of the effector, the number of other effectors released by the pathogen, and their functional redundancy (Goverse and Struik 2009; Kwon et al. 2008; Michelmore et al. 2013; Stirnweis et al. 2014), and compensatory mutations in other loci (Gabriel 1999; Laine and Barrès 2013; Wolfe 1984). In the hop powdery mildew pathosystem, it is unknown if the virulence gained by $P$. macularis in overcoming $R 6$ imposed a fitness penalty on the fungus, and whether there is some residual value in this defeated $R$ gene as a QTL.

The objectives in this research were several fold. The research sought to: (i) describe the geographic extent and severity of powdery mildew on cultivars with $R 6$ and $R 6$-virulent isolates of $P$. macularis, (ii) identify the race of $R 6$-virulent isolates of the fungus, and (iii) determine whether overcoming $R 6$ was associated with a reduction in fitness in P. macularis.

\section{Materials and Methods}

Plant materials. Hop plants of various cultivars were propagated from softwood cuttings and maintained in a greenhouse kept free of powdery mildew by vaporizing sulfur nightly for $2 \mathrm{~h}$. The greenhouse was maintained at 20 to $25^{\circ} \mathrm{C}$ with a 14-h photoperiod. Plants were grown in Sunshine Mix number 1 (Sun Gro Horticulture) for approximately 14 to 21 days and watered regularly, receiving Sunshine Technigro 16-17-17 Plus fertilizer with micronutrients (Sun Gro Horticulture) with each irrigation. Isolates of $P$. macularis were maintained on detached hop leaves (Wolfenbarger et al. 2015). To do this, young, unfurled leaves from the top node of hop plants were detached, surface disinfested with $70 \%$ ethanol, rinsed for $30 \mathrm{~s}$ with deionized water, and allowed to air dry. Disinfested leaves were placed in double petri dishes (Pearson and Gadoury 1987) with the petiole placed in water in the lower petri dish. Isolates of the fungus were inoculated using a dissecting needle and transferred every 2 to 3 weeks.

Race characterization of $\boldsymbol{P}$. macularis isolates. During 2012 to 2014, 31 samples of leaves and cones were collected from commercial hop yards or greenhouses in Oregon (15 isolates) and Washington (16 isolates) and found to possess $R 6$ virulence, as described below. The samples were collected from 'Apollo' (four isolates); 'Bravo' (two isolates); 'Summit' (one isolate); 'Columbus', 'Tomahawk', and 'Zeus', collectively called CTZ (two isolates); Nugget (seven isolates); 'Millennium' (two isolates); 'Newport' (one isolate); 'Serebrianka' (one isolate); 'El Dorado' (one isolate); 'Super Galena' (three isolates); 'Mt. Hood' (two isolates); 'Willamette' (two isolates); 'Tettnanger' (two isolates); and 'Magnum' (one isolate). An additional 11 samples that lacked $R 6$ virulence were obtained from cultivars that lacked $R 6$, including Magnum ( 3 isolates), CTZ (1 isolate), 'Galena' ( 1 isolate), 'Cascade' ( 3 isolates), 'Sterling' ( 1 isolate), and a breeding line ( 2 isolates). Clonal isolates were obtained by inoculation of a single fungal conidial chain onto detached leaves of 'Symphony' (susceptible to powdery mildew and not known to possess any $R$ genes) or Nugget (which possesses $R 6$ ), as described by Wolfenbarger et al. (2015). Isolates were maintained through successive transfers of conidia onto the powderymildew-susceptible Symphony, with routine transfers on to Nugget to ensure selection for $R 6$ virulence.

To determine the race of isolates of $P$. macularis, clonal isolates were inoculated to three detached hop leaves from each plant of a differential set of cultivars with the aid of a dissecting microscope and a small insect-pinning needle. Isolates able to grow on cultivars containing unique resistance factors were deemed to contain the corresponding virulence. 'Yeoman' $(R b)$, 'Zenith' ( $R b$ and $R l)$, 'Target' $(R 2)$, 'Challenger' ( $R b$ and $R 3)$, Serebrianka $(R 4)$, 'Early Choice' $(R 5)$, and Nugget $(R 6)$ were used as the differential set. Although Zenith and Challenger are reported to contain $R b$ in addition to another $R$ gene, the phenotype for $R b$ appears to be dependent on environment and routinely is not observed in vitro (D. H. Gent, personal observation). Validation of the differential set was conducted before studies began by inoculating each of the cultivars with two to three isolates of $P$. macularis obtained from E. Seigner (Bayerische Landesanstalt für Landwirtschaft, Bavaria, Germany), which were previously characterized to race in independent experiments (Seigner et al. [2006]).

For race characterization of isolates collected in the current study, leaves were rated for the presence or absence of powdery mildew after 21 days of incubation at $18^{\circ} \mathrm{C}$ with a 14 -h light regimen. A reaction was considered positive if conidiophores of the fungus were visible with $\times 40$ magnification.

Surveys for powdery mildew on cultivars with $R 6$-based resistance. Surveys were conducted in Oregon and Washington during 2012, 2013, and 2014 to determine the incidence and prevalence of powdery mildew on cultivars possessing $R 6$ and their relative susceptibility to powdery mildew. The hop production regions in western Oregon have a wet, marine west coast climate, in contrast to the semiarid climate where hops are produced in southcentral Washington. Each year, 20 to 21 hop yards were sampled for powdery mildew in the hop-growing regions of Washington (designated Yakima Indian Reservation, Moxee, Lower Valley) on Apollo, Bravo, Millennium, and Nugget. Other cultivars possess $R 6$ but this survey was not intended to be exhaustive of all cultivars believed to possess $R 6$. Rather, cultivars were selected that were relatively widely planted in Washington, where growers permitted sampling on their farms, and represented varying genetic ancestry. In Oregon, presence and incidence of powdery mildew in commercial hop yards was determined by surveys of 11 to 15 hop yards planted to Nugget and Super Galena during 2012 to 2014. Cultivars were selected based on access to these cultivars in this state.

In both states, disease assessments were conducted during early to mid-July using established sampling methods for powdery mildew on leaves (Gent et al. 2006; Turechek and Mahaffee 2004). In brief, two transects (rows) were selected arbitrarily in each yard and 10 leaves were inspected for the presence of powdery mildew on each of 75 plants per transect. In Washington, hop cones were collected and rated for powdery mildew and yards were assessed for powdery mildew postharvest using a modification of the leaf-sampling method. For cone sampling, from each of 20 plants in a single transect (row), cones were collected from heights of approximately 3,4 , and $5 \mathrm{~m}$ and bulked. From this composite sample, 25 cones per plant were randomly selected. Cones were inspected under $\times 10$ to $\times 50$ magnification for the presence of conidiophores of the fungus, and deemed to have powdery mildew if at least one conidiophore was detected. Disease assessments conducted postharvest were as described for leaf sampling, except that all remaining foliage on the plants was assessed and disease incidence was expressed at the plant scale. From these data, the incidence of leaves, cones, or plants with powdery mildew was estimated for each yard. 
Pesticide application records were obtained from cooperating growers at the end of each season to determine the number of fungicide applications made specifically for powdery mildew. For the purpose of this study, mixtures of two powdery mildew fungicides used in a single application were considered one application. Disease incidence data from leaves, cones, and postharvest plants and number of fungicide applications were analyzed by state over all years in a generalized linear mixed model using the GLIMMIX procedure in SAS (version 9.4; SAS Institute). Fixed factors evaluated were cultivar and, in Washington, production region. For the Washington data, yard nested within production region and year of sampling were considered random factors. For the Oregon data, analysis of cultivar effects considered hop yard and year of sampling to be random factors. Analysis of production region was not considered for Oregon because the industry is smaller and does not have geographically distinct production regions as in Washington. Trends in incidence of disease and fungicide applications made over time also were assessed by considering year a fixed factor and hop yard within region (Washington data) or simply hop yard (Oregon data) a random factor. Normal distribution of the response variables was specified in the analyses using the default identity link function in the GLIMMIX procedure. Disease incidence data for cones were subjected to angular transformation, and postharvest disease incidence was log-transformed before analysis based on residual diagnostics.

A confounding source when conducting disease assessments in commercial fields is varying epidemic severity, which can be caused by differing weather, local inoculum density, and fungicide applications that are applied unevenly to different fields and cultivars. Controlled experiments at multiple locations with artificial inoculation can overcome these limitations but, with a long-lived perennial crop such as hop, establishment may take several years in an experimental plot. This adds substantial costs and may not be feasible due to legal and ethical restrictions in regions where a pathogen or strain of a pathogen does not yet exist. In this study, these tradeoffs were considered and it was determined that timely information on cultivar susceptibility obtainable from surveys of commercial yards was more critical in the short-term than the long-term (yet more controlled) studies in experimental plots.

To obtain some information from a semicontrolled study, plots not treated with fungicides were established in two commercial yards of Nugget in Washington during each of 2012, 2013, and 2014. Each nontreated plot was at least five rows wide and at least $100 \mathrm{~m}$ in length. During late May to early August of each year, assessments of powdery mildew were conducted biweekly by assessing 10 leaves from each of 75 plants in the middle row of the nontreated plot. Mean disease incidence on each sampling date was summarized and compared with results from the survey described previously.

Frequency of $\boldsymbol{R} \boldsymbol{\sigma}$-virulent isolates of $\boldsymbol{P}$. macularis on cultivars lacking R6. To assess the distribution and spread of $R 6$-virulent isolates of $P$. macularis, powdery mildew samples were collected during August and September in 2012, 2013, and 2014 from hop yards planted to cultivars lacking $R 6$ in Oregon and Washington. The number of hop yards sampled ranged from one to nine hop yards each year in Oregon and in the three production regions within Washington. The yards sampled were planted to CTZ, Cascade, 'Centennial', 'Chinook', Magnum, Sterling, Willamette, Meridian, El Dorado, Galena, Sterling, 'Warrior', and an unnamed breeding line. From each of these yards, two to five leaves or cones with powdery mildew were collected, and transferred as a heterogeneous inoculum source (not reduced to a clonal isolate) onto detached leaves of Symphony. In total, 5 to 49 samples were isolated from a given production region within a year, for a total of 81 (in 2012), 159 (in 2013), and 151 (in 2014) isolates. After 2 to 3 weeks of incubation on Symphony, inoculum from each sample was transferred to three leaves of Nugget to determine the presence of $R 6$-virulent isolates of $P$. macularis using the methods stated above.

Differences in the frequency of $R 6$-virulent isolates of the fungus between production regions were quantified using a generalized linear mixed model in SAS. For each year, region was considered a fixed effect and hop yard nested with region was a random factor.
A binomial distribution and logit link function were specified in the model. The association between frequency of occurrence of $R 6$-virulent isolates of $P$. macularis on cultivars lacking $R 6$ and the incidence of powdery mildew on cultivars with $R 6$ in the same region as determined from the disease surveys was assessed by simple linear regression using the REG procedure in SAS.

Frequency of $R 6$-virulent isolates of $P$. macularis from the eastern United States. To determine whether isolates capable of overcoming $R 6$ were found in the United States outside of the Pacific Northwest, samples were obtained from cooperating growers and scientists in New York, Maryland, Minnesota, Michigan, and North Carolina. Samples were grown on Symphony for 10 to 14 days before being transferred to Nugget to test for R6 virulence. In 2012, nine samples were received from New York from an unknown heritage cultivar along with eight from wild hop plants. Also in 2012, 14 samples from wild hop plants found in Maryland were received. Four samples from Minnesota were received from an unnamed breeding line in 2013. Samples received in 2015 were reported to be from the following cultivars: two from Newport and three from 'Yakima Gold' from Michigan, five from 'Cashmere' from North Carolina, one from Cascade and two from Nugget from New York, five from an unnamed breeding line in Minnesota, as well as four from unknown cultivars from a greenhouse in Michigan.

Susceptibility of hop plants possessing $R 6$ and fitness of R6virulent isolates. Growth chamber studies. To determine whether the defeated $R 6$ gene has any residual value in disease suppression, 23 individuals were obtained from a mapping population developed from a cross of the powdery-mildew-susceptible Perle and resistant male USDA 19058M (Henning et al. 2011). This population was previously phenotyped using isolates of $P$. macularis lacking $R 6$ virulence. Individuals also were genotyped by amplified fragment length polymorphism and DArT (diversity array technology) fingerprinting methods and, as noted previously, two genetic markers linked to disease susceptibility were identified (Henning et al. 2011).

In all, 12 individuals were arbitrarily selected from the population that had both susceptibility markers present and were susceptible to powdery mildew, and 11 individuals were selected that lacked the susceptibility markers and were resistant to powdery mildew. Resistant genotypes were deemed to contain $R 6$ because these individuals were immune to isolates of $P$. macularis lacking $R 6$ virulence (Henning et al. 2011) but susceptible to isolates which had $R 6$ virulence in preliminary studies.

From each individual, three to six leaves were detached, surface disinfested, and placed in the double petri-dish system described previously (Pearson and Gadoury 1987). The leaves were inoculated with an equal mixture of three clonal isolates of $P$. macularis obtained from Washington in 2012 with confirmed $R 6$ virulence or three clonal isolates of $P$. macularis from Oregon that lacked $R 6$ virulence. Inoculations were conducted by applying a suspension of each inoculum source at 50,000 conidia/ml with an airbrush sprayer (item number 0226; Preval). Three leaves of Symphony and Nugget were inoculated with each inoculum source as controls to ensure viability of inoculum. Noninoculated leaves were included as a check against background infection. The leaves were incubated at $18^{\circ} \mathrm{C}$ with a 14-h photoperiod provided by fluorescent lights ( $32 \mathrm{~W}$, Philips F32T8/TL850 800 series Alto Fluorescent).

Measurements of latent period, infection severity, and conidia production were made to detect differences in these components of pathogenic fitness. Latent period was determined by nondestructively inspecting each leaf daily with the aid of a stereomicroscope (up to $\times 50$ magnification) for the presence of conidiophores for $P$. macularis. The number of days when at least $50 \%$ of the leaves for each genotype bore sporulation of the fungus was considered the latent period. After 10 to 11 days of incubation, the equivalent to approximately two latent periods on a susceptible cultivar at $18^{\circ} \mathrm{C}$ (Turechek et al. 2001), the number of lesions was determined with the aid of a stereomicroscope on each leaf and then standardized by leaf area. The number of conidia produced was quantified by rinsing conidia from leaves with an airbrush sprayer and counting the spores in an aliquot of the suspension with the aid of a hemocytometer. The experiment 
was randomized and blocked temporally four times in a complete block design. Data were analyzed in a general linear mixed model with fixed factors for (i) presence of $R 6$ in the host and (ii) virulence of the fungus. Replication of the experiment and host genotype nested within replication were considered random factors.

Field studies. To further determine whether plants possessing $R 6$ develop less powdery mildew than plants that do not, 12 of the individuals from the mapping population that lacked $R 6$ and 11 individuals that possessed $R 6$ were selected from the growth chamber study described above. These individuals were grown in pots in a greenhouse free of powdery mildew and planted in a field at the Lewis Brown Farm near Corvallis, OR on 20 June 2013. Two pots of each individual were planted in each plot, with each individual replicated in four plots in a randomized complete block design. The plants were grown under a trellis that was approximately $1.5 \mathrm{~m}$ tall with a single string per plant, and watered by drip irrigation as needed for normal development.

In 2014 and 2015, the plants were inspected to ensure that all were free of powdery mildew. Later on the same day, individuals lacking $R 6$ were inoculated with the same isolates used in the growth chamber study that lacked $R 6$ virulence. Plants possessing $R 6$ were inoculated with a mixture of three isolates possessing $R 6$ virulence, each of which was collected from commercial hop yards in Oregon during 2013. The titer of inoculum applied to both sets of plants was 50,000 spores/ml. Inoculum was applied to all leaves on the plants until just before runoff using a hand-pump sprayer. The incidence of powdery mildew was assessed twice beginning 2 weeks after inoculation by inspecting 10 leaves per plant for the presence of powdery mildew. Differences in disease levels between plants possessing $R 6$ and those that did not were analyzed using a mixed-effect model. The presence or absence of $R 6$ was a fixed effect and the individual plant line nested within genotype was a random factor. After angular transformation of the data, analyses were conducted in GLIMMIX using default settings for the distribution and link function.

A potential source of confounding in this study was ambient inoculum of $P$. macularis that could disperse into the plots and differentially infect plants with or without $R 6$. To infer inoculum dispersal into and out of the plots, plants of Symphony and Nugget were produced from softwood cuttings in a greenhouse and eventually potted into 4-liter pots. These plants were then placed in a shaded area outdoors on the Oregon State University campus, approximately $4 \mathrm{~km}$ to the west of the nearest known hop yard, and held for 7 days to acclimate to outdoor growth conditions. After this period, the plants were deployed in vectors on the leeward and windward side of the yard, relative to the primary westerly wind direction. On each of two to three dates in 2014 and 2015, two plants of each cultivar were deployed for 48 -h periods in and near the plots at the Lewis Brown Farm. The pots were placed in the center of the plot and at distances of $0.9,1.5,2,3,4.6,6.1,9.1,13.7$, and $18.3 \mathrm{~m}$ to the west and east from the center. After $48 \mathrm{~h}$ of exposure, the potted plants were moved to a greenhouse and maintained at 22 to $25^{\circ} \mathrm{C}$ for a further 10 days of incubation. The powdery mildew lesions per leaf were then counted and used to construct disease gradients to depict the primary direction of inoculum dispersal, ensuring that dispersal of exogenous sources of $P$. macularis into the plots was inconsequential.

\section{Results}

Race characterization of Podosphaera macularis isolates. All 31 isolates collected from cultivars possessing $R 6$ or possessing $R 6$-virulent races of $P$. macularis contained the virulence factors $\mathrm{Vb}, \mathrm{V} 3, \mathrm{~V} 4, \mathrm{~V} 5$, and V6 (Table 1). Eleven isolates unable to infect Nugget (and, thus, lacking $R 6$ virulence) had similar virulence, with the exception that these isolates lacked V4 and V6 virulence (Table 2). Therefore, no isolates of $P$. macularis were identified in this collection that were capable of infecting plants possessing $R 1$ or $R 2$ in the Pacific Northwest.

Surveys for powdery mildew on cultivars with R6-based resistance. In Washington, powdery mildew was detected on the foliage in 12 of the 20 (60\%) hop yards sampled in 2012, 14 of $21(66.7 \%)$ in 2013 , and 13 of $21(61.9 \%)$ in 2014 when assessed in July. On cones, the disease was detected in $76 \%$, $45 \%$ and $73 \%$ of the yards in 2012, 2013 and 2014, respectively. The disease was detected postharvest from $95 \%, 90 \%$, and $66 \%$ of yards in 2012 , 2013, and 2014, respectively.

Temporal changes in disease incidence on cultivars possessing $R 6$ were not detected on leaves midseason $(P=0.602$; Fig. 1A) or cones $(P=0.510$; Fig. 1B) but there was a significant decrease in disease levels postharvest from 2012 to 2014 (Fig. $1 C ; P=0.025$ ). When analyzed over all years, differences in the incidence of leaves with powdery mildew midseason were found among cultivars (Fig. 1D), with disease levels being significantly greater on Millennium as compared with the others $(P=0.001)$. Disease incidence was similar on cones among cultivars $(P=0.106$; Fig. $1 \mathrm{E})$, although there was weak evidence $(P=0.074)$ that the incidence of plants with powdery mildew postharvest was greater on Apollo than Nugget (Fig. 1F). In the nontreated Nugget plots during 2012 to 2014 , powdery mildew was never found on more than $0.3 \%$ of leaves (data not presented). In no situation were greater than $3.4 \%$ of cones found with powdery mildew in the nontreated plots.

Correspondingly, the intensity of fungicide applications by growers varied by cultivar (Fig. 2). On average, growers made 4.6 to 6.4 applications per year to Bravo and Apollo, respectively; significantly more than the 1.9 to 2.3 made to Millennium and Nugget $(P=0.001)$.

Regional differences in disease incidence were apparent on leaves midseason $(P=0.033)$. Disease levels were greatest in yards located on the Yakima Indian Reservation but similar in Moxee and the Lower Valley production regions (Fig. 3A). This regional effect was not significant later in the season on cones or postharvest $(P \geq 0.102$; Fig. 3B and C). Intensity of fungicide applications also varied among production regions $(P=0.021)$. The greatest number of fungicide applications was made in the Lower Valley production region (5.5 per year), intermediate on the Yakima Indian Reservation (3.3 per year), and least in Moxee (2.4 per year) (Fig. 2B).

In Oregon, the disease was not detected in the 11 yards surveyed in 2012. In 2013 and 2014, powdery mildew was detected in 4 of 15 (26.7\%) and 8 of $14(57.1 \%)$ yards, respectively. The incidence of powdery mildew on foliage increased on cultivars possessing $R 6$ during 2012 to 2014 ( $P=0.027$; Fig. 4A). The incidence of leaves with powdery mildew was significantly greater in Super Galena than Nugget $(P=0.0005$; Fig. 4B), although these cultivars received a similar number of fungicide applications on average (3.8 in Super Galena and 2.9 in Nugget; $P=0.296$ ).

In both Oregon and Washington, the annual number of fungicide applications increased during 2012 to 2014 (Fig. 5). The number of applications made in Washington steadily increased up to 4.8 applications per yard in 2014 whereas, in Oregon, application intensity increased more precipitously to 6.3 per yard as the disease became more widespread in 2014 (year, $P<0.0001$; year-state interaction, $P=0.016)$.

Frequency of $\boldsymbol{R} \boldsymbol{\sigma}$-virulent isolates of $\boldsymbol{P}$. macularis on cultivars lacking $\boldsymbol{R 6}$. The frequency of occurrence of isolates of $P$. macularis possessing $R 6$ virulence on cultivars lacking $R 6$ resistance increased during 2012 to 2014. In 2012, no such isolates were detected, whereas region-dependent occurrence of $R 6$-virulent isolates was found in both 2013 and 2014 (Table 3). Regional and temporal differences in frequency of $R 6$-virulent isolates was correlated with regional disease pressure on cultivars possessing $R 6$, as determined from the midseason disease assessments $(r=0.75 ; P=0.005)$.

Frequency of $R 6$-virulent isolates of $P$. macularis from the eastern United States. In total, 57 isolates were obtained from the eastern United States. $R 6$ virulence was not detected in any of the isolates assayed.

Susceptibility of hop plants possessing $R 6$ and fitness of R6-virulent isolates. Growth chamber studies. Among individuals from the Perle $\times$ USDA 19058 M mapping population, isolates of the powdery mildew fungus with $R 6$ virulence had a significantly longer latent period (an increase from 5.22 to 6.03 days; $P<0.0001$ ) and produced fewer lesions $(P<0.0001)$ on plants with $R 6$ as 
compared with plants lacking R6 (Fig. 6). Isolates of the fungus with $R 6$ virulence produced fewer conidia as compared with isolates lacking $R 6$ virulence, independent of whether the isolates were grown on a plant with or without $R 6(P=0.049)$.
Field studies. In both years, trap plants deployed in the $48 \mathrm{~h}$ after inoculation were free of powdery mildew, indicating that background sources of inoculum were insignificant. In all instances, disease gradients on trap plants decreased exponentially with distance from the

Table 1. Race characterization of Podosphaera macularis isolates possessing $R 6$ virulence

\begin{tabular}{|c|c|c|c|c|c|c|c|c|c|c|}
\hline \multirow[b]{2}{*}{ Isolate } & \multirow[b]{2}{*}{ Year } & \multirow[b]{2}{*}{ State $^{x}$} & \multirow[b]{2}{*}{ Original cultivar } & \multicolumn{7}{|c|}{$R$ gene and differential cultivarw } \\
\hline & & & & $R b$ Yeoman & R1 Zenith & $R 2$ Target & R3 Challenger & R4 Serebrianka & $\begin{array}{c}R 5 \text { Early } \\
\text { Choice }\end{array}$ & R6 Nugget \\
\hline HPM-194 & 2013 & WA & Newport & + & - & - & + & + & + & + \\
\hline HPM-195 & 2013 & WA & Apollo & + & - & - & + & + & + & + \\
\hline HPM-196 & 2013 & WA & Nugget & + & - & - & + & + & + & + \\
\hline HPM-197 & 2013 & WA & Serebrianka & + & - & - & + & + & + & + \\
\hline HPM-317 & 2013 & WA & Apollo & + & - & - & + & + & + & + \\
\hline HРM-319 & 2013 & WA & Bravo & + & - & - & + & + & + & + \\
\hline HPM-576 & 2013 & WA & Apollo & + & - & - & + & + & + & + \\
\hline HPM-582 & 2013 & WA & El Dorado ${ }^{y}$ & + & - & - & + & + & + & + \\
\hline HPM-587 & 2013 & WA & Zeus $^{\mathrm{y}}$ & + & - & - & + & + & + & + \\
\hline HPM-475 & 2013 & OR & Super Galena & + & - & - & + & + & + & + \\
\hline HPM-573 & 2013 & OR & Nugget & + & - & - & + & + & + & + \\
\hline HPM-577 & 2013 & OR & Nugget & + & - & - & + & + & + & + \\
\hline HPM-607 & 2013 & OR & Mt. Hood & + & - & - & + & + & + & + \\
\hline HPM-608 & 2013 & OR & Mt. Hood & + & - & - & + & + & + & + \\
\hline HРM-609 & 2013 & OR & Nugget & + & - & - & + & + & + & + \\
\hline HPM-610 & 2013 & OR & Nugget & + & - & - & + & + & + & + \\
\hline HPM-662 & 2014 & OR & Super Galena & + & - & - & + & + & + & + \\
\hline HРM-664 & 2014 & OR & Willamette $^{\mathrm{y}}$ & + & - & - & + & + & + & + \\
\hline HPM-665 & 2014 & OR & Nugget & + & - & - & + & + & + & + \\
\hline HРM-666 & 2014 & WA & Apollo & + & - & - & + & + & + & + \\
\hline HPM-667 & 2014 & WA & Summit & + & - & - & + & + & + & + \\
\hline HPM-670 & 2014 & WA & $\mathrm{CTZ}^{\mathrm{y}}$ & + & - & - & + & + & + & + \\
\hline HPM-672 & 2014 & WA & Bravo & + & - & - & + & + & + & + \\
\hline HPM-673 & 2014 & OR & Tettnanger $^{\mathrm{y}}$ & + & - & - & + & + & + & + \\
\hline HPM-674 & 2014 & OR & Super Galena & + & - & - & + & + & + & + \\
\hline HPM-675 & 2014 & OR & Willamette ${ }^{\mathrm{y}}$ & + & - & - & + & + & + & + \\
\hline HPM-680 & 2014 & OR & Magnumy & + & - & - & + & + & + & + \\
\hline HPM-682 & 2014 & OR & Tettnanger ${ }^{\mathrm{y}}$ & + & - & - & + & + & + & + \\
\hline HPM-700 & 2014 & WA & Nugget & + & - & - & + & + & + & + \\
\hline HPM-731 & 2014 & WA & Millennium & + & - & - & + & + & + & + \\
\hline HPM-736 & 2014 & WA & Millennium & + & - & - & + & + & + & + \\
\hline Virulent $(\%)^{\mathrm{z}}$ & $\ldots$ & $\ldots$ & $\ldots$ & 100 & 0 & 0 & 100 & 100 & 100 & 100 \\
\hline
\end{tabular}

Table 2. Race characterization of Podosphaera macularis isolates lacking $R 6$ virulence

\begin{tabular}{|c|c|c|c|c|c|c|c|c|c|c|}
\hline \multirow[b]{2}{*}{ Isolate } & \multirow[b]{2}{*}{ Year } & \multirow[b]{2}{*}{ State $^{\mathbf{y}}$} & \multirow[b]{2}{*}{ Original cultivar } & \multicolumn{7}{|c|}{$R$ gene and differential cultivar ${ }^{x}$} \\
\hline & & & & $R b$ Yeoman & R1 Zenith & $R 2$ Target & R3 Challenger & $R 4$ Serebrianka & $\begin{array}{c}R 5 \text { Early } \\
\text { Choice }\end{array}$ & R6 Nugget \\
\hline HPM-328 & 2013 & OR & Breeding line & + & - & - & + & - & + & - \\
\hline HРM-333 & 2013 & OR & Sterling & + & - & - & + & - & + & - \\
\hline HPM-338 & 2013 & OR & Magnum & + & - & - & + & - & + & - \\
\hline HPM-661 & 2014 & OR & Magnum & + & - & - & + & - & + & - \\
\hline HРМ-663 & 2014 & OR & Magnum & + & - & - & + & - & + & - \\
\hline HРМ-668 & 2014 & OR & Breeding line & + & - & - & + & - & + & - \\
\hline НРМ-669 & 2014 & WA & Tomahawk & + & - & - & + & - & + & - \\
\hline HРМ-671 & 2014 & WA & Galena & + & - & - & + & - & + & - \\
\hline HРМ-693 & 2014 & WA & Cascade & + & - & - & + & - & + & - \\
\hline HРМ-694 & 2014 & WA & Cascade & + & - & - & + & - & + & - \\
\hline HPM-697 & 2014 & WA & Cascade & + & - & - & + & - & + & - \\
\hline Virulent $(\%)^{\mathrm{z}}$ & $\ldots$ & $\ldots$ & $\ldots$ & 100 & 0 & 0 & 100 & 0 & 100 & 0 \\
\hline
\end{tabular}

$\mathrm{x}$ A reaction was deemed positive (+) if sporulation was observed by 21 days after inoculation. Each isolate was inoculated onto each of 3 leaves of each differential cultivar.

$\mathrm{y}$ WA $=$ Washington and OR $=$ Oregon.

${ }^{\mathrm{z}}$ Percentage of isolates virulent on each cultivar. 
center of plots on the leeward side of the field (Supplementary Fig. S1). Therefore, the primary source of airborne conidia appeared to emanate from the inoculated plots and no evidence of an exogenous source of inoculum was found.
The extent of powdery mildew suppression on plants possessing $R 6$ in field studies was not consistent over years. In 2014, the incidence of leaves with powdery mildew was reduced by at least half on plants possessing $R 6$ as compared with those without $R 6$
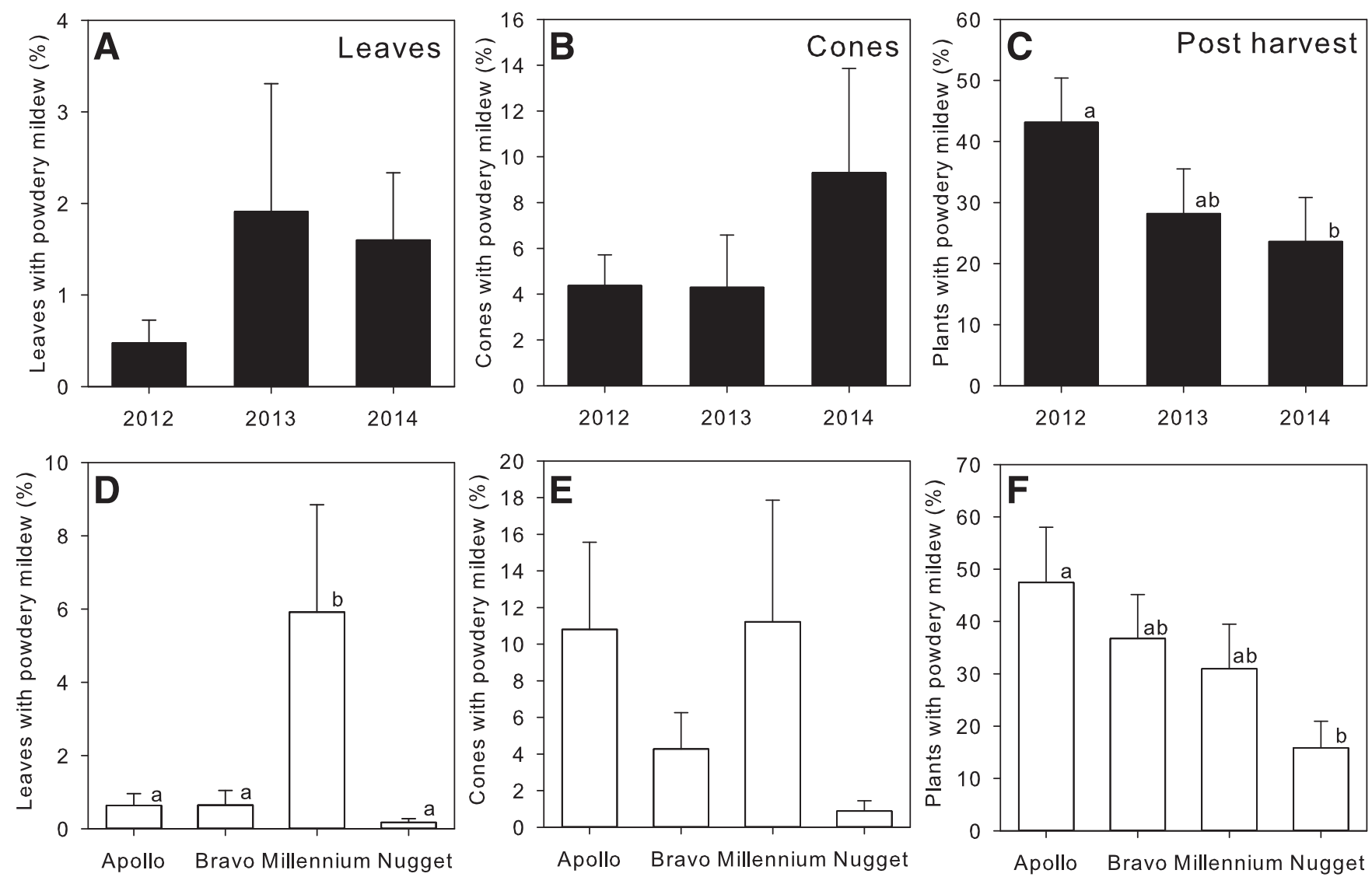

Fig. 1. Incidence of hop powdery mildew (caused by Podosphaera macularis) on leaves in early July, cones at harvest, and plants postharvest A, B, and C, during 2012 to 2014 in Washington and $\mathbf{D}, \mathbf{E}$, and $\mathbf{F}$, among four cultivars collectively over these years. Values with different letters are significantly different based on upon a mixed-model analysis at $P=0.05$ in $C$ and $D$ and $P=0.074$ in $F$. Figure plates without letters indicate no significant differences were detected. Error bars represent standard errors.
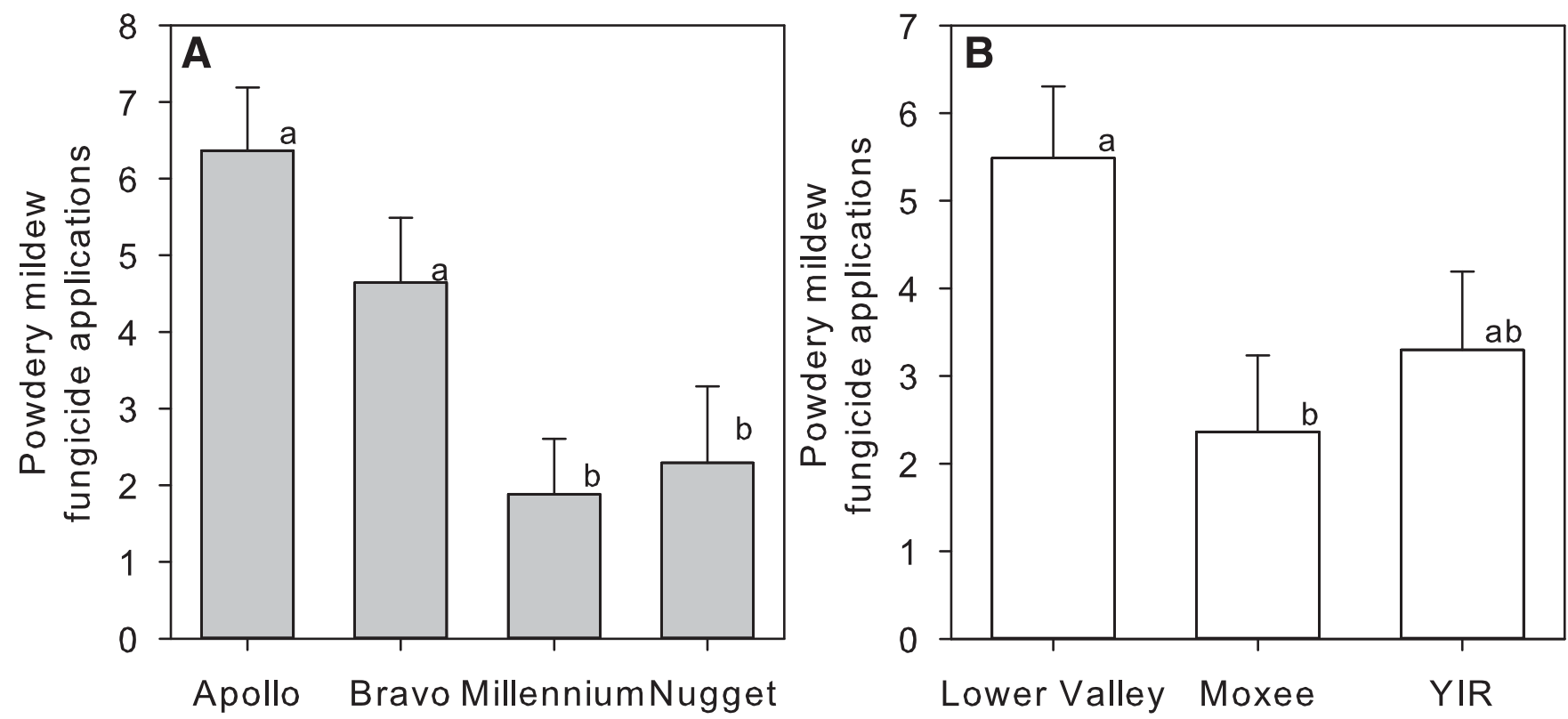

Fig. 2. Average ( \pm standard error) fungicide applications made for powdery mildew (caused by Podosphaera macularis) on selected hop cultivars possessing R6 and among production regions in Washington during 2012 to 2014 . YIR = Yakima Indian Reservation. Values with different letters are significantly different based on upon a mixed-model analysis $(P=0.05)$. 
(Table 4). However, in 2015, the incidence of leaves with powdery mildew was statistically similar (Table 4).

\section{Discussion}

R6-based resistance provided a level of disease suppression that was equivalent to immunity to powdery mildew in the Pacific Northwest for 14 years. This was a crucial component of disease management programs developed following the destructive epidemics that followed the introduction of $P$. macularis to the Pacific Northwest in the mid 1990s (Ocamb et al. 1999). This research demonstrates that isolates of $P$. macularis capable of overcoming $R 6$ resistance are now widespread in the region and outbreaks of powdery mildew occur annually on formerly resistant cultivars. In 2012, disease outbreaks were initially limited to Washington and were not observed in Oregon. However, outbreaks were reported by growers of Apollo in southern Idaho during August 2012 and P. macularis isolates with $R 6$ virulence were obtained from this cultivar that year. In 2013, powdery mildew was detected in three hop yards planted to Nugget and Super Galena in Oregon. During 2014, disease outbreaks became relatively widespread in Oregon.
$R 6$-virulent isolates of the fungus are now broadly established in the U.S. Pacific Northwest but were not confirmed in isolates derived from the Upper Midwest or eastern United States. Although diseased leaves of cultivars identified as Newport and Nugget were received from outside of the Pacific Northwest, both of which are reported to possess $R 6$ (Wolfenbarger et al. 2014a), $R 6$ virulence was unable to be confirmed in this work. The lack of $R 6$ virulence in these isolates may reflect the presence of susceptible, off-type cultivars (i.e., cultivars other than Nugget or Newport) in the yards where the samples were collected because it is common for contamination of rootstock to occur in hop yards due to the crop being vegetatively propagated.

Results from the surveys indicate a progressive increase in the prevalence of $R 6$-virulent isolates in the population, increasing occurrence and incidence of disease outbreaks, and increasing intensity of fungicide applications made by growers. However, there was considerable variation in disease levels between individual yards (Figs. 1 and 4; note the large error bars) which, together with the temporal trend for increasing severity of outbreaks, indicate that primary inoculum density may still be limiting to epidemic development. As the
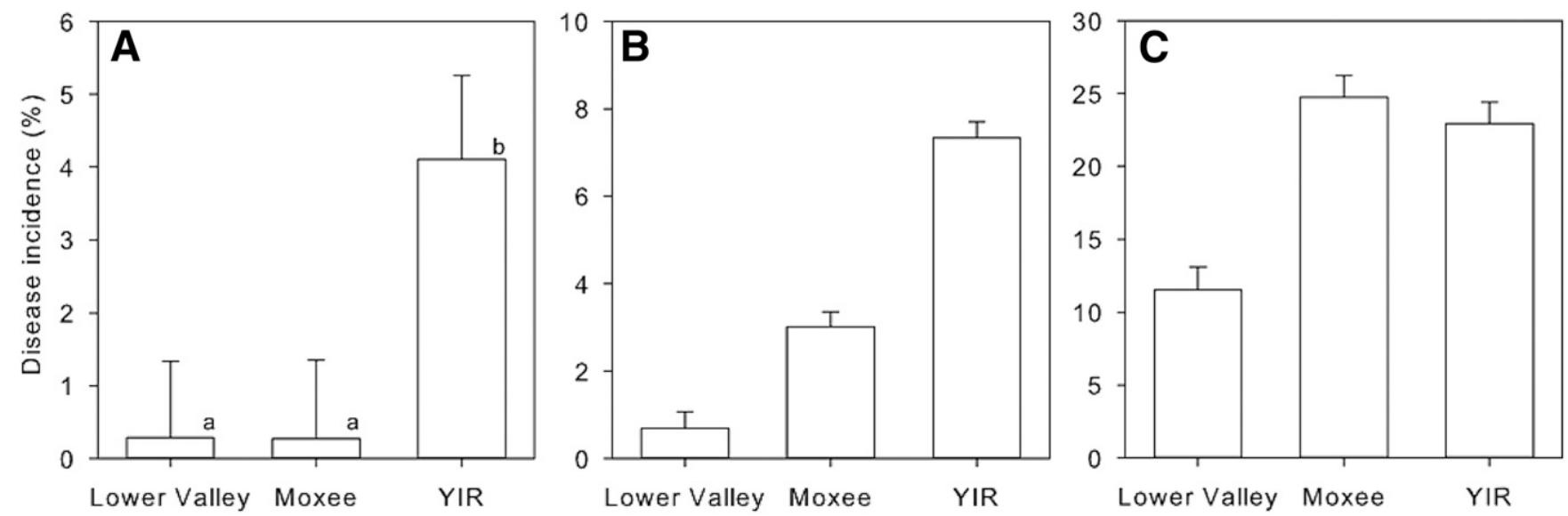

Fig. 3. Incidence of powdery mildew (caused by Podosphaera macularis) on A, hop leaves in July; B, cones at harvest; and C, plants postharvest during 2012 to 2014 in Washington among three production regions (YIR = Yakima Indian Reservation). Values with different letters are significantly different based on upon a mixed-model analysis $(P=0.05)$. Figure plates without letters indicate no significant differences were detected. Error bars represent standard errors.
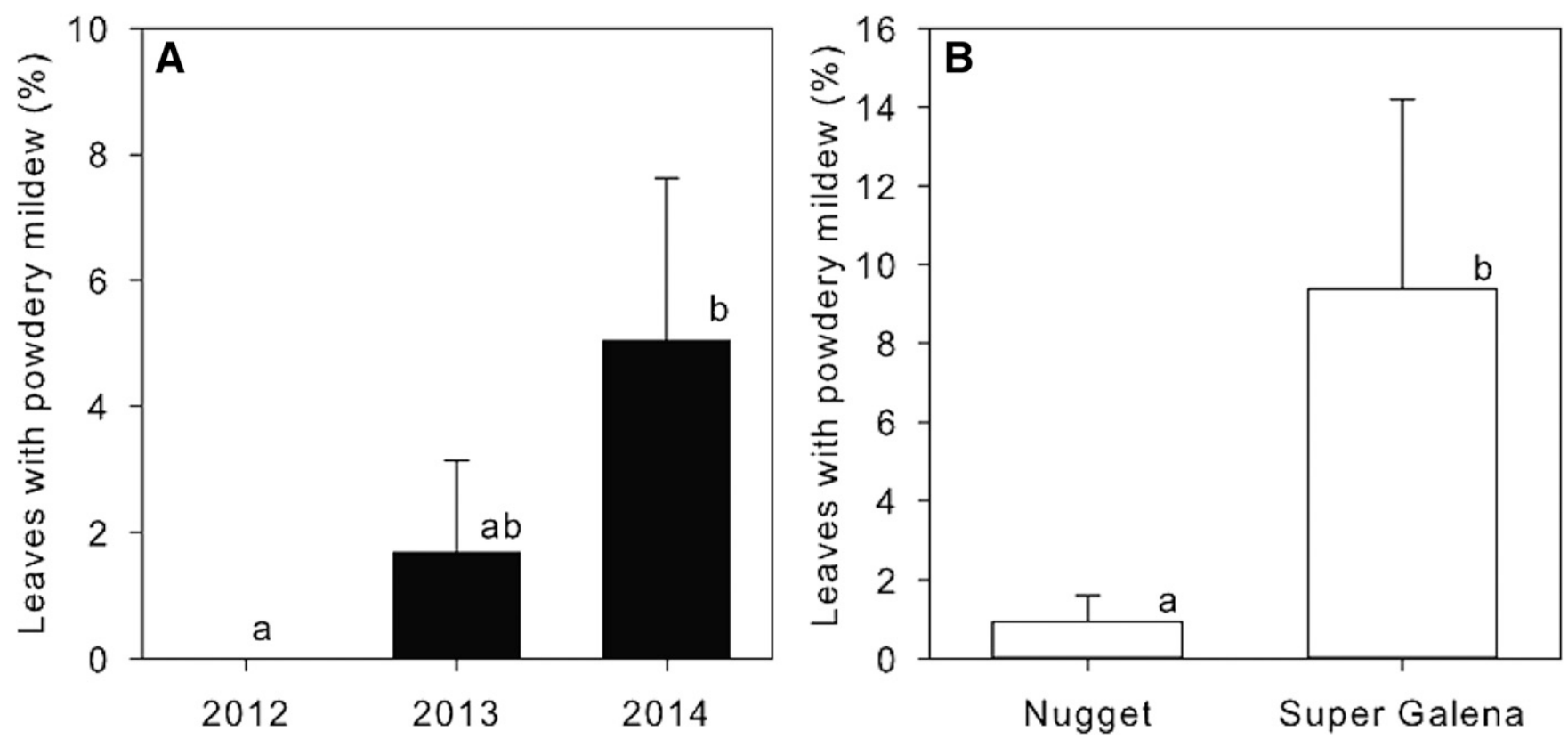

Fig. 4. Incidence of hop leaves with powdery mildew (caused by Podosphaera macularis) A, during 2012 to 2014 and B, on two cultivars possessing R6 in Oregon in late June to early July during these years. Values with different letters are significantly different based on upon a mixed-model analysis $(P=0.05)$. Error bars indicate standard errors. 
pathogen becomes established and perennates in more yards, the onset of powdery mildew likely will be earlier and disease escape in certain yards less likely.

Regional differences in the incidence of symptomatic leaves and cones were detected in Washington during the 3 years of these studies, with the greatest incidence of the disease on both leaves and cones in yards in the Yakima Indian Reservation production area. Turechek et al. (2001) similarly conducted an extensive survey of powdery mildew in hop yards (those lacking $R 6$ ) in Washington and Oregon and found broadly similar regional differences in disease incidence. These differences undoubtedly reflect the integration of several factors, including regional differences in early-season inoculum density, climatic factors, and management tendencies of the growers in regions. Precisely quantifying the role of each of these factors on disease levels with observational data are not possible. There was, however, a general correspondence between disease levels and the intensity of fungicide applications made by growers. The most fungicide applications for powdery mildew were made in hop yards in the Lower Valley production region, where disease levels on leaves and cones were correspondingly the lowest.

Differences in disease levels and fungicide use patterns were detected among cultivars, suggesting differential susceptibility to powdery mildew. In Washington, Apollo and, to a lesser extent, Bravo received fungicide programs of an intensity approaching that typical of highly susceptible cultivars (Gent et al. 2012; Sherman and Gent 2014). Millennium and Nugget were treated at an intermediate to low intensity (zero to four applications), depending on the production region and year. Disease incidence on leaves tended to be greatest on Millennium, which could be partially confounded by region-specific factors even though these were controlled for in the mixed-model analysis.

The disease assessments conducted postharvest reduced confounding effects from fungicide use because these ratings were conducted approximately 4 to 6 weeks after the cessation of the fungicide spray program. The trend $(P=0.074)$ for cultivar effects in postharvest levels of powdery mildew is of interest, and suggests that there is a difference in susceptibility between Apollo and Nugget. Taken together with the fungicide use data provided by growers, it is reasonable to conclude that Apollo is relatively susceptible to powdery mildew given both the levels of disease recorded postharvest and the intensity in which growers applied fungicides to this cultivar. In Washington, Nugget appears to be the least susceptible of the

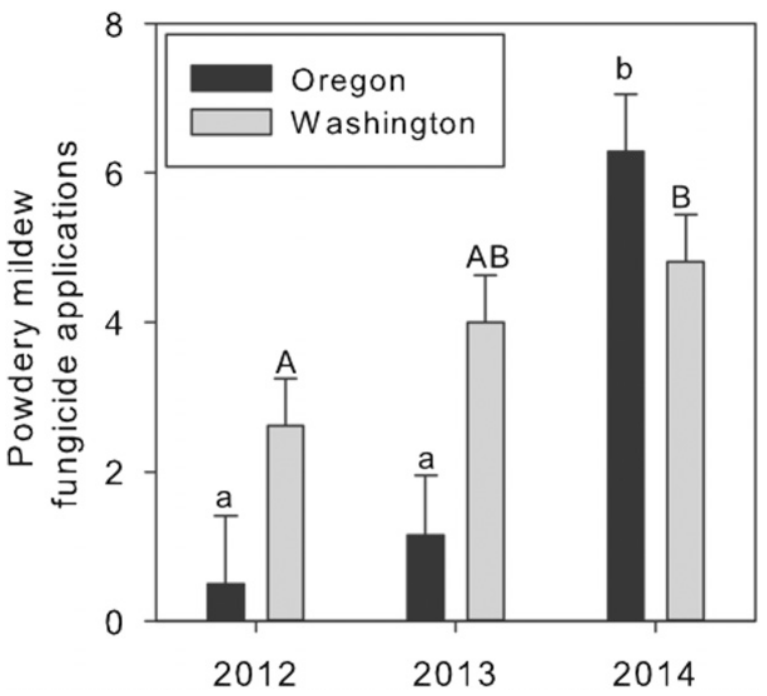

Fig. 5. Average ( \pm standard error) fungicide applications made for powdery mildew (caused by Podosphaera macularis) on hop cultivars possessing R6 in Oregon and Washington during 2012 to 2014. In Oregon, data are reported for Nugget and Super Galena. In Washington, data are reported for Apollo, Bravo, Millennium, and Nugget. Within a state, values with different letters are significantly different based on upon a mixed-model analysis $(P=0.05)$. cultivars evaluated based on the infrequency of fungicide applications made by growers and low level of powdery mildew development on leaves, on cones, or postharvest. This assertion is also supported by the trace levels of powdery mildew that developed in the nontreated plots established in commercial yards of Nugget. We caution that these findings may be heavily influenced by regional inoculum pressure, which is situation dependent; therefore, these results provide only a general indication of the relative susceptibility of these cultivars.

There appears to be a difference in the powdery mildew reaction of Nugget when grown in Oregon versus Washington. This is supported by the overall greater incidence of powdery mildew on leaves and intensity of fungicide applications made by growers in each state. Similar observations of greater susceptibility of cultivars when grown in Oregon as compared with Washington have been previously reported (Turechek et al. 2001). Prior exposure of hop plants to high temperature reduces leaf susceptibility to powdery mildew (Mahaffee et al. 2003), and there is a general correlation between cuticular thickness and leaf susceptibility to powdery mildew in several hosts (Martin 1964). The apparent differential reaction of Nugget may be due to differences in the climate that tend to lead to less susceptible leaf tissue in Washington as compared with Oregon, or potentially temperaturedependent resistance in this cultivar. Central Washington experiences supraoptimal conditions for powdery mildew more frequently than western Oregon (Turechek et al. 2001), which is known to moderate susceptibility of hop to the disease (Mahaffee et al. 2003).

The prevalence of $R 6$-virulent isolates of $P$. macularis on cultivars lacking $R 6$ provides a general measure of regional inoculum density and previous dispersal of inoculum. Since 2012, there has been an increase in the frequency of detection of $R 6$-virulent isolates on other cultivars although, in any given year, the frequency of these isolates varied. The interannual variation in frequency of detection of R6virulent isolates of the fungus in the population was related to the severity of powdery mildew on cultivars with $R 6$, the presumable source of this inoculum. For organisms capable of long-distance dispersal, the velocity and extent of spread of epidemics is multiplicatively related to primary inoculum density (Madden et al. 2007). Regional differences in frequency of R6-virulent isolates of the fungus, then, are likely correlated with variation in the degree of overwintering inoculum, given that initial inoculum density is a primary determinant of dispersal potential (Mundt et al. 2011, 2013). P. macularis perennates in the U.S. Pacific Northwest in infected buds on hop plants at a low frequency (less than $0.5 \%$ of plants on average) (Gent et al. 2008) due to the absence of the ascigerious stage in this region (Wolfenbarger et al. 2015). The dispersal and prevalence of $R 6$ virulent isolates of the fungus may reflect where and to what extent the fungus overwintered and conditions during the early phases of epidemic development. As of 2015, R6-virulent isolates of $P$. macularis have not yet been confirmed from the eastern United States.

Growth of $P$. macularis on plants with $R 6$ appears to be associated with a fitness cost to the fungus. A fitness penalty associated with defeat of major gene resistance has been noted in several other

Table 3. Frequency of Podosphaera macularis isolates possessing $R 6$ virulence (V6) on hop cultivars lacking resistance gene $R 6^{\mathrm{z}}$

\begin{tabular}{lcccccccc}
\hline & \multicolumn{2}{c}{$\mathbf{2 0 1 2}$} & & \multicolumn{2}{c}{$\mathbf{2 0 1 3}$} & & \multicolumn{2}{c}{$\mathbf{2 0 1 4}$} \\
\cline { 2 - 3 } Region & Isolates & V6 (\%) & & Isolates & V6 (\%) & & Isolates & V6 (\%) \\
\hline Lower Valley & 5 & 0 & & 25 & $8.0 \mathrm{a}$ & & 29 & $10.3 \mathrm{~b}$ \\
Moxee & 25 & 0 & & 40 & $2.5 \mathrm{a}$ & & 25 & $12 \mathrm{~b}$ \\
YIR & 16 & 0 & & 49 & $44.9 \mathrm{~b}$ & & 38 & $7.9 \mathrm{~b}$ \\
Oregon & 35 & 0 & & 45 & 0 & & 59 & $45.7 \mathrm{a}$ \\
\hline
\end{tabular}

$\mathrm{z}$ Within a year, means followed by the same letter are not significantly different based on mixed-model analysis $(P=0.05)$. Lower Valley, Moxee, and Yakima Indian Reservation (YIR) refer to hop production regions in central Washington. Analysis was not conducted with the 2012 data due to the absence of detection of R6-virulent isolates of the fungus. Samples collected from Oregon were not included in statistical analyses in 2013 due to the absence of powdery mildew on cultivars possessing $R 6$. 
pathosystems (Van der Plank 1968). Isolates with R6 virulence exhibited reduced sporulation compared with isolates lacking $R 6$ virulence. There is evidence that the presence of $R 6$ itself contributes an additional level of quantitative resistance, as compared with plants lacking $R 6$, as indicated by longer latent period and reduced frequency of lesions produced by the same isolates when inoculated onto plants with $R 6$ versus those lacking $R 6$. The overall influence of these effects manifested in field studies was season dependent. At present, it is unclear whether the influence of these differences can be generalized beyond the particular mapping population used in this study. The results may be idiosyncratic to this population due to linkage of $R 6$ to other loci associated with quantitative resistance. Nonetheless, the findings from the growth chamber and field studies suggest that follow-up studies with diverse genotypes are warranted to determine whether $R 6$ has some persisting value as a QTL.

Race characterization in this study detected only two races present in the Pacific Northwest: one race was unable to infect hop with $R 6$ resistance and had virulence $\mathrm{Vb}, \mathrm{V} 3$, and V5; and the newly emerged race was able to infect hop with $R 6$ resistance and had virulence $\mathrm{Vb}$, V3, V4, V5, and V6 (Wolfenbarger et al. 2014b). Although the two races differ in the ability to infect plants with $R 6$, the emerging race is further capable of infecting Serebrianka, which is reported to contain $R 4$ (Seigner et al. 2006). Superficially, it appears that two $R$ genes have been overcome; however, to our knowledge, no cultivar possessing $R 4$ is widely grown in the United States. There are several potential scenarios that may explain how two $R$ genes were overcome when only one was broadly deployed. The avirulence effector loci in the fungus may be linked, and both may have been lost due to a mutation or other recombination event, as reported in other pathosystems (Van de Wouw et al. 2010). Alternatively, $R 4$ and $R 6$ may, in fact, be the same gene or allele but may have been characterized incorrectly. Another possibility is that there was a new introduction of $P$. macularis to the region which, by chance, happened to possess $R 4$ and $R 6$ virulence. The latter scenario seems unlikely: the race of $R 6-$ virulent strains is similar to commonly found strains present in the region, with only the addition of $R 6$ and $R 4$ virulence. Further, the $R 6$-virulent strains are exclusively mating type $M A T 1-1$, whereas both mating types occur at roughly a one-to-one ratio in other populations outside of the U.S. Pacific Northwest (Wolfenbarger et al. 2015). Given these two aspects, it is more likely that an extant strain gained $R 6$ virulence through a mutation or other nonmeiotic recombination event.

Although $R 6$ may, in fact, be a susceptibility factor (Henning et al. 2011), $R 6$ behaves fundamentally differently than MLO. Unlike
MLO, $R 6$ is race specific and was not durable over multiple decades, and $R 6$ virulence does not impose a large fitness penalty on $P$. macularis. Looking forward, then, breeding programs that desire resistance based on single $R$ genes in the Pacific Northwest region are left with only $R I$ and $R 2$ (or other $R$ genes yet to be discovered) because all other known $R$ genes tested can be overcome by strains of the pathogen. Resistance based on a single $R$ gene is not expected to be durable and the failure of a single, major $R$ gene is likely to be repeated again if $R 1, R 2$, or other single $R$ genes are broadly deployed. Combining multiple $R$ genes or combining $R$ genes with underlying quantitative resistance is possible and is predicted to be more durable (McDonald 2014). To this end, diverse sources of resistance with underlying quantitative resistance are urgently needed.

In the short term, management of powdery mildew on all of these cultivars will require adopting practices commonly deployed on other susceptible cultivars such as thorough spring pruning (Gent et al. 2012), canopy management such as removal of basal foliage (Gent et al. 2008), careful consideration of harvesting timing (Gent et al. 2014; Mahaffee et al. 2009), and appropriate deployment of fungicides (Nelson et al. 2015). The cost of implementing these practices will be substantial in individual hop yards and in aggregate to the industry.

Table 4. Incidence of hop leaves with powdery mildew (caused by Podosphaera macularis) in relation to presence or absence of the resistance gene $R 6^{\mathrm{y}}$

\begin{tabular}{lccccc}
\hline & \multicolumn{2}{c}{2014} & & \multicolumn{2}{c}{2015} \\
\cline { 2 - 3 } \cline { 5 - 6 } Genotype $^{\mathbf{z}}$ & 5 June & 20 June & & 2 June & 9 June \\
\hline$R 6$ & $4.1 \mathrm{a}$ & $2.0 \mathrm{a}$ & & $19.3 \mathrm{a}$ & $5.3 \mathrm{a}$ \\
Non- $R 6$ & $8.3 \mathrm{~b}$ & $4.9 \mathrm{~b}$ & & $26.1 \mathrm{a}$ & $6.6 \mathrm{a}$ \\
\hline
\end{tabular}

$\mathrm{y}$ Within a year and evaluation date, means followed by the same letter are not significantly different based on mixed-model analysis $(P=0.05)$. Genotype of the hop (presence or absence of $R \sigma$ ) was a fixed effect and the individual line from the mapping population nested within genotype was a random factor.

${ }^{\mathrm{z}}$ Individuals from a Perle $\times$ USDA $19058 \mathrm{M}$ mapping population with confirmed presence (11 individuals) or absence (12 individuals) of $R 6$ were challenged with a corresponding batch of inoculum containing a mixture of three isolates of Podosphaera macularis possessing R6 virulence or lacking R6 virulence. Inoculations occurred on 21 May 2014 and 19 May 2015. Incidence of powdery mildew was assessed on the dates indicated above by inspecting 10 leaves arbitrarily selected per plant for the presence of powdery mildew.
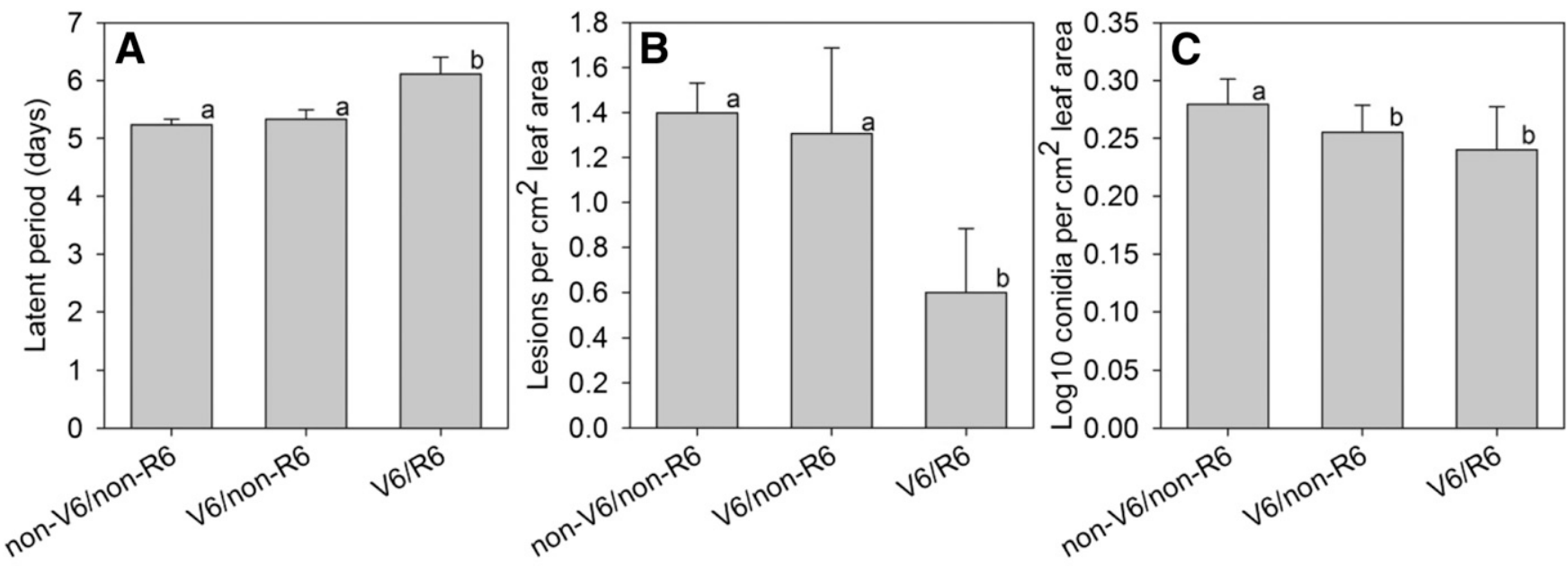

\section{Pathogen virulence / hop genotype}

Fig. 6. Measures of quantitative resistance and pathogenic fitness components among isolates of Podosphaera macularis with and without $R 6$ virulence (V6) and on hop genotypes with or without the powdery mildew resistance factor $R 6$. For a given variable, values with different letters are significantly different based on upon a mixed-model analysis $(P=$ 0.05). Error bars indicate standard errors. 


\section{Acknowledgments}

Financial support was provided by the United States Department of AgricultureAgricultural Research Service CRIS 2072-21000-046-00, the Hop Research Council, Washington Hop Commission, Washington State Commission on Pesticide Registrations, and Western IPM Center (grant agreement number SA7762). We thank D. Gadoury for his suggestions and comments that improved this article; and the many people who provided powdery mildew samples for this project: D. Gadoury, J. Havill, D. Higgins, R. Jeske, R. Kaitany, C. Rowher, E. Seigner, and M.-J. Welser.

\section{Literature Cited}

Agrios, G. 2005. Plant Pathology, 5th ed. Elsevier Academic Press, San Diego, CA.

Ellis, J. G., Lawrence, G. J., Luck, J. E., and Dodds, P. N. 1999. Identification of regions in alleles of the flax rust resistance gene $L$ that determine differences in gene-for-gene specificity. Plant Cell 11:495-506.

Flor, H. 1955. Host-parasite interaction in flax rust-its genetics and other implications. Phytopathology 45:680-685.

Gabriel, D. W. 1999. Why do pathogens carry avirulence genes? Physiol. Mol. Plant Pathol. 55:205-214.

Gent, D. H., Grove, G. G., Nelson, M. E., Wolfenbarger, S. N., and Woods, J. L. 2014. Crop damage caused by powdery mildew on hop and its relationship to late season management. Plant Pathol. 63:625-639.

Gent, D. H., Mahaffee, W. F., and Turechek, W. W. 2006. Spatial heterogeneity of the incidence of powdery mildew on hop cones. Plant Dis. 90:14331440 .

Gent, D. H., Nelson, M. E., George, A. E., Grove, G. G., Mahaffee, W. F., Ocamb, C. M., et al. 2008. A decade of hop powdery mildew in the pacific northwest. Online publication. Plant Health Prog. doi:10.1094/PHP-2008-0314-01-RV

Gent, D. H., Nelson, M. E., Grove, G. G., Mahaffee, W. F., Turechek, W. W., and Woods, J. L. 2012. Association of spring pruning practices with severity of powdery mildew and downy mildew on hop. Plant Dis. 96: 1343-1351.

Goverse, A., and Struik, P. 2009. Debate on the exploitation of natural plant diversity to create late blight resistance in potato. Potato Res. 52:265-271.

Henning, J. A., Townsend, M. S., Gent, D. H., Bassil, N., Matthews, P., Buck, E., and Beatson, R. 2011. QTL mapping of powdery mildew susceptibility in hop (Humulus lupulus L.). Euphytica 180:411-420.

Jones, J. D. G., and Dangl, J. L. 2006. The plant immune system. Nature 444: 323-329.

Jørgensen, I. 1992. Discovery, characterization and exploitation of Mlo powdery mildew resistance in barley. Euphytica 63:141-152.

Kwon, C., Neu, C., Pajonk, S., Yun, H. S., Lipka, U., Humphry, M., Bau, S., Straus, M., Kwaaitaal, M., Rampelt, H., El Kasmi, F., Jürgens, G., Parker, J., Panstruga, R., Lipka, V., and Schulze-Lefert, P. 2008. Co-option of a default secretory pathway for plant immune responses. Nature 451:835-840.

Laine, A.-L., and Barrès, B. 2013. Epidemiological and evolutionary consequences of life-history trade-offs in pathogens. Plant Pathol. 62:96-105.

Leach, J. E., Vera Cruz, C. M., Bai, J., and Leung, H. 2001. Pathogen fitness penalty as a predictor of durability of disease resistance genes. Annu. Rev. Phytopathol. 39:187-224.

Madden, L. V., Hughes, G., and Van den Bosch, F. 2007. The Study of Plant Disease Epidemics. American Phytopathological Society, St. Paul, MN.

Mahaffee, W. F., Engelhard, B., Gent, D. H., and Grove, G. G. 2009. Powdery mildew. Pages 25-31 in: Compendium of Hop Diseases and Pests. W. M. Mahaffee, S. J. Pethybridge, and D. H. Gent, eds. American Phytopathological Society, St. Paul, MN.

Mahaffee, W. F., Turechek, W. W., and Ocamb, C. M. 2003. Effect of variable temperature on infection severity of Podosphaera macularis on hops. Phytopathology 93:1587-1592.

Martin, J. 1964. Role of cuticle in the defense against plant disease. Annu. Rev. Phytopathol. 2:81-100.

McDonald, B. A. 2014. Using dynamic diversity to achieve durable disease resistance in agricultural ecosystems. Trop. Plant Pathol. 39:191-196.

Michelmore, R. W., Christopoulou, M., and Caldwell, K. S. 2013. Impacts of resistance gene genetics, function, and evolution on a durable future. Annu. Rev. Phytopathol. 51:291-319.

Mundt, C. C., Sackett, K. E., and Wallace, L. D. 2011. Landscape heterogeneity and disease spread: experimental approaches with a plant pathogen. Ecol. Appl. 21:321-328.
Mundt, C. C., Wallace, L. D., Allen, T. W., Hollier, C. A., Kemerait, R. C., and Sikora, E. J. 2013. Initial epidemic area is strongly associated with the yearly extent of soybean rust spread in North America. Biol. Invasions 15: 1431-1438.

Nelson, M. E., Gent, D. H., and Grove, G. G. 2015. Meta-analysis reveals a critical period for management of powdery mildew on hop cones. Plant Dis. 99:632-640.

Nelson, R. 2012. The evolution of parasitic fitness. Pages 23-46 in: Plant Disease: An Advanced Treatise, Vol. 4. How Pathogens Induce Disease. J. G. Horsfall and E. B. Cowling, eds. Academic Press, New York.

Neve, R. 1991. Hops. Chapman and Hall, London.

Nürnberger, T., and Lipka, V. 2005. Non-host resistance in plants: New insights into an old phenomenon. Mol. Plant Pathol. 6:335-345.

Ocamb, C. M., Klein, R., Barbour, J., Griesbach, J., and Mahaffee, W. 1999. First report of hop powdery mildew in the Pacific Northwest. Plant Dis. 83:1072.

Pearson, R., and Gadoury, D. M. 1987. Cleistothecia, the source of primary inoculum for grape powdery mildew in New York. Phytopathology 77: 1509-1514.

Salmon, E. 1917. The value of hop-breeding experiments. J. Inst. Brew. 23:60-97.

Schouten, H. J., Krauskopf, J., Visser, R. G. F., and Bai, Y. 2014. Identification of candidate genes required for susceptibility to powdery or downy mildew in cucumber. Euphytica 200:475-486.

Seifi, A., Gao, D., Zheng, Z., Pavan, S., Faino, L., Visser, R. G. F., Wolters, A.-M. A. and Bai, Y. 2014. Genetics and molecular mechanisms of resistance to powdery mildews in tomato (Solanum lycopersicum) and its wild relatives. Eur. J. Plant Pathol. 138:641-665.

Seigner, E., Lutz, A., and Felsenstein, F. G. 2006. Wild hops: New genetic resources for resistance to hop powdery mildew (Podosphaera macularis spp. humuli). Brew. Sci. Monatsschr. Brauwiss. 59:122-129.

Seigner, E., Seefelder, S., Haugg, B., Hesse, H., Rosch, H., and Felsenstein, F. 2001. Investigations on the virulence spectrum of hop powdery mildew (Sphaerotheca humuli) and on the effectiveness of race-specific resistance genes. Pages 40-43 in: Proc. Sci. Comm. Int. Hop Grow. Conv. Canterbury, England. E. Seigner, ed.

Sherman, J., and Gent, D. H. 2014. Concepts of sustainability, motivations for pest management approaches, and implications for communicating change. Plant Dis. 98:1024-1035.

Stirnweis, D., Milani, S. D., Brunner, S., Herren, G., Buchmann, G., Peditto, D. Jordan, T., and Keller, B. 2014. Suppression among alleles encoding nucleotidebinding-leucine-rich repeat resistance proteins interferes with resistance in F1 hybrid and allele-pyramided wheat plants. Plant J. 79:893-903.

Stotz, H. U., Mitrousia, G. K., de Wit, P. J. G. M., and Fitt, B. D. L. 2014. Effectortriggered defence against apoplastic fungal pathogens. Trends Plant Sci. 19:491-500.

Thompson, J. N., and Burdon, J. J. 1992. Gene-for-gene coevolution between plants and parasites. Nature 360:121-125.

Turechek, W. W., and Mahaffee, W. F. 2004. Spatial pattern analysis of hop powdery mildew in the Pacific Northwest: Implications for sampling. Phytopathology 94:1116-1128.

Turechek, W. W., Mahaffee, W. F., and Ocamb, C. M. 2001. Development of management strategies for hop powdery mildew in the Pacific Northwest. Online publication. Plant Health Prog. doi:10.1094/PHP-2001-0313-01-RS

Van der Plank, J. E. 1968. Disease Resistance in Plants. Academic Press, London.

Van de Wouw, A. P., Cozijnsen, A. J., Hane, J. K., Brunner, P. C., McDonald, B. A., Oliver, R. P., and Howlett, B. J. 2010. Evolution of linked avirulence effectors in Leptosphaeria maculans is affected by genomic environment and exposure to resistance genes in host plants. Online publication. PLoS Pathog. doi: 10.1371/journal.ppat. 1001180

van Schie, C. C. N., and Takken, F. L. W. 2014. Susceptibility genes 101: How to be a good host. Annu. Rev. Phytopathol. 52:551-581.

Wolfe, M. 1984. Trying to understand and control powdery mildew. Plant Pathol. 33:451-466.

Wolfenbarger, S. N., Eck, E. B., and Gent, D. H. 2014a. Characterization of resistance to powdery mildew in the hop cultivars Newport and Comet. Online publication. Plant Health Prog. doi:10.1094/PHP-BR-13-0129.

Wolfenbarger, S. N., Eck, E. B., Ocamb, C. M., Nelson, M. E., Grove, G. G., and Gent, D. H. 2014b. Powdery mildew outbreaks caused by Podosphaera macularis on hop cultivars possessing the resistance gene R6 in the Pacific Northwestern United States. Plant Dis. 98:852.

Wolfenbarger, S. N., Twomey, M. C., Gadoury, D. M., Knaus, B. J., Grünwald, N. J., and Gent, D. H. 2015. Identification and distribution of the mating-type locus and development of cleistothecia of Podosphaera macularis. Plant Pathol. 64:1094-1102. 